\title{
The Impact of Learning Management and Teacher Performance on Student's Learning Outcomes in Junior High School at Tulung Selapan District
}

\author{
Arnubi $^{\left.1^{*}\right)}$, Bukman Lian ${ }^{2}$, Mulyadi $^{2}$ \\ ${ }^{1}$ SD Negeri 1 Tulung Seluang \\ ${ }^{2}$ Universitas PGRI Palembang \\ *Corresponding author. Email: tabikarnubi@gmail.com

\begin{abstract}
Learning management is intended as the management of learning carried out by teachers in the classroom. Therefore, it is believed that good management can have a good impact on the implementation of learning. The main objective of this research is to provide a clear description of the effect of learning management and teacher performance partially and simultaneously on student learning outcomes at public Junior High School (SMP Negeri) Tulung Selapan District. Research implementation to the process of analysis and reporting of research results is carried out using quantitative methods. Based on the data obtained through questionnaires, observation, and documentation, it can be concluded that learning management has a significant and positive influence on student learning outcomes. Likewise, with testing carried out partially on teacher performance variables, giving a significant and positive effect on student learning outcomes. When tested simultaneously, it is known that learning management and teacher performance can have a significant and positive impact on student learning outcomes at SMP Negeri Tulung Selapan District.
\end{abstract}

Keywords: Learning management, Teacher performance, Learning outcomes.

\section{INTRODUCTION}

Education is an expectation for everyone to improve themselves, the quality of the economy, and even the quality of life. Education plays an important role in transforming knowledge and value, through education a person is able to develop his potential to be more optimal. The existence of education makes skills more felt. Through education also the understanding of things can be done from various points of view or perspectives. Thus, studying a problem can be done with various solutions resulting from various aspects.

This description is an educational objective that has been formulated by the Constitution of the Republic of Indonesia, through Law No. 20 of 2003 which specifically regulates the national education system. In article 3, it is explained that national education is organized with the aim of developing the potential of learners to become human beings who believe in an almighty God, good character, healthy, knowledgeable, capable, creative, independent, and become democratic and responsible citizens [1].
Achieving the goal of education nationally is not as easy as turning your palm, but it takes hard work from every element of interest in education. Each position has responsibilities by its duties and functions. Therefore, if one of the positions does not carry out its main duties and functions properly then the objectives of education will not be achieved. Many factors can influence the achievement of national educational goals.

If examined more deeply, then there is the main element that is directly confronted in the implementation of education, in case is teachers as the vanguard that delivers learning materials. That's why a teacher is declared a professional because everyone can't become a teacher in formal education even if everyone can give knowledge. As professionals, teachers have a high enough responsibility to succeed in the implementation of education.

Learning management or managing learning is an activity that needs to be managed by teachers during the interaction process with students in the implementation of learning. Learning management contains the process of managing activities that begin with planning, organizing, directing, controlling, and assessing [2]. 
based on this understanding, it can be understood that the management of learning or learning, is indeed the obligation of every teacher who teaches. That way, the achievement of learning objectives can be continuously measured every time the learning process is completed. If it can be done well, then the learner's understanding of the learning material will be more optimal, and the implications of the learner's learning outcomes will be better.

Currently, learning held informal education units is growing rapidly. Diverse forms of learning by utilizing diverse resources add to the scientific characteristics to be more felt. The use of the right media and strategies to optimization of learning can be implemented by teachers in the process of knowledge transformation. The use of media and other things in learning needs to be managed properly by teachers so that the other implication is that the teacher's performance becomes better.

If you look deeply, then the sections are interconnected. Teachers as educators who directly come face to face with learners have the task of managing or managing learning, which ultimately gives students the ability to understand the material until the learning outcomes increase. Similarly, good management of learning by teachers will also have an impact on their performance achievements. Therefore, basically, teachers must be able to properly manage learning.

One of the components in teacher performance assessment is the management of learning in the classroom, so the performance of teacher is to carry out the activities of learning both outside the classroom and inside the classroom in addition to doing other activities, such as school administration and learning administration, carrying out services and guidance to the students, as well as carrying out assessments [3].

Understanding the performance of teachers will make each teacher more productive and able to create innovations in the implementation of learning. If this is realized, then the learner can easily understand the learning material, which means that the results obtained by learners from the learning process become more. According to Sudjana [4], student learning outcomes are essentially behavioral changes as a consequence of learning in a broader sense covering cognitive, affective, and psychomotor fields.

Other definitions also presented by Dimyati and Mudjiono [5] mention the results of learning as a consequence of a synergy of learning and teaching actions. From the teacher's side, the teaching action ends with the process of evaluating the learning results. From the student side, the result of learning is the end of teaching from the top of the learning process. If the definitions are observed, then it is fitting that the learner's learning outcomes will be better if a teacher is able to manage the learning well and perform well.

These reasons are still assumptions until they can be proven empirically through the results of this study. As it is known that the research to be done should have a reference or reference about similar research that has been done. Similar research was conducted by Ratnawati [6]. The result is that learning management has a positive and significant effect on the teacher's performance in realizing student learning achievement.

Supporting the researchers' assumptions about the important reason this research needs to do is that there are still teachers who have not managed their learning in the classroom properly. The management of learning that has not been done properly by teachers is due to the understanding of learning management is not yet well understood. So that the impact also on the performance of teachers, because incomprehension related to quality learning management causes the administration of learning to be not optimal. As a result of all that, it also has an impact on students who learn, so that students' achievements on the material studied become low which means that the student's learning outcomes are not optimal.

The above description explains that it is important to conduct in-depth studies related to learning management, teacher performance, and student learning outcomes. Therefore, this study was aimed to provide an explanation of the influence of learning management and performance of teacher on student learning outcomes partially and simultaneously.

\section{METHODS}

The implementation of this research was conducted in SMP Negeri Tulung Selapan District. The research began in July to September 2020. The implementation of research has many methods that can be used, but in this research used is quantitative method. The selection of this method is believed to be more appropriate to answer the formulation of research problems. Quantitative study methods based on positivism philosophy to study the specific populations, data collection using instruments of research, statistical data analysis, with the aim of testing the established hypotheses [7].

Similarly, Sugiyono [8] stated that quantitative study method is a research method depends on the positivism, used to research on certain populations, random sampling, the use of research instruments for data 
collection, quantitative or statistical data analysis to test the hypothesis that has been determined.

Based on the description, it is clear that quantitative research methods are appropriate to be used so that the formulations of research problems can be answered with empirical explanations. The study sample was obtained from a portion of the population of 226 people out of 446. Sample determination is done by the purposive sampling technique.

To obtain research data, the researchers used observation techniques, documentation, and questionnaires. For the questionnaire, 56 statements related to variables were examined.

\section{RESULTS AND DISCUSSION}

The data obtained from the results of the study were then analyzed through pre-reassessed tests that resulted in information that the data distributed normally and did not occur symptoms of heteroscedasticity. Therefore, the analysis is done through parametric statistics with ttest and $\mathrm{F}$ test.

\subsection{Hypothesis Testing 1}

The results obtained from the testing of this hypothesis are as follows:

Table 1.Test Result "t-Test"

\begin{tabular}{|c|c|c|c|c|c|}
\hline \multicolumn{6}{|c|}{ Coefficients ${ }^{\mathrm{a}}$} \\
\hline \multirow[b]{2}{*}{ Model } & \multicolumn{2}{|c|}{\begin{tabular}{l|} 
Unstandardized \\
Coefficients
\end{tabular}} & \multirow{2}{*}{$\begin{array}{l}\text { Standardized } \\
\text { Coefficients }\end{array}$} & \multirow[b]{2}{*}{$t$} & \multirow[b]{2}{*}{ Sig. } \\
\hline & $\mathrm{B}$ & Std. Error & & & \\
\hline 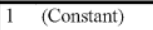 & 36,433 & 2,293 & & 15,891 &, 000 \\
\hline $\begin{array}{l}\text { Manajemen } \\
\text { Pembelajaran }\end{array}$ & ,576 &, 029 & ,802 & 20,103 & , 000 \\
\hline
\end{tabular}

Source: processed data (October 2020)

The $t$ value for the learning management variable is $20,103>\mathrm{t}$ table which is 1,971 which means that learning management has a significant and positive influence on student learning outcomes in SMP Negeri Tulung Selapan.

Table 2. Coefficient of Determinants (H1)

\begin{tabular}{|l|c|r|r|r|}
\hline Model & R & R Square & $\begin{array}{c}\text { Adjusted R } \\
\text { Square }\end{array}$ & $\begin{array}{c}\text { Std. Error of the } \\
\text { Estimate }\end{array}$ \\
\hline 1 &, $802^{\mathrm{a}}$ &, 643 &, 642 & 1,14551 \\
\hline
\end{tabular}

Source: processed data (October 2020)

The correlation coefficient or relationship between learning management and student learning outcomes in SMP Negeri Tulung Selapan is $80.2 \%$ and belongs to the category of strong relationships. The coefficient of determinant or the amount of learning influence management variables on learning outcomes of student in SMP Negeri Tulung Selapan is $64.3 \%$ which means it has a high influence.

\subsection{Hypothesis Testing 2}

The results obtained from the second hypothesis test are as follows:

Table 3. Test Result "t-Test"

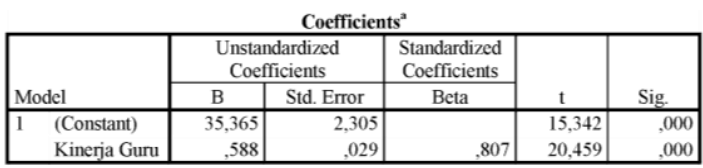

Source: processed data (October 2020)

The t-count is 20,459 for teacher performance testing of learning outcomes. From this value, it is interpreted in the table $t$ value of 1,971 which means $t$ calculate > t Table; 20,459 > 1,971. Based on this, there is a significant and positive influence of teacher performance on the learning outcomes of students in SMP Negeri Tulung Selapan Subdistrict.

The relationship and effect of teacher performance variables on student learning outcomes in SMP Negeri Tulung Selapan Subdistrict can be seen in the following table.

Table 4. Determinant Coefficient (H2)

\begin{tabular}{|l|c|r|r|r|}
\multicolumn{7}{|c|}{ Model Summary } \\
\hline Model & \multicolumn{1}{|c|}{ R } & R Square & $\begin{array}{c}\text { Adjusted R } \\
\text { Square }\end{array}$ & $\begin{array}{c}\text { Std. Error of the } \\
\text { Estimate }\end{array}$ \\
\hline 1 &, $807^{\mathrm{a}}$ &, 651 &, 650 & 1,13257 \\
\hline
\end{tabular}

Source: processed data (October 2020)

The correlation coefficient or magnitude of the relationship between teacher performance and student learning outcomes was $80.7 \%$. The size of the relationship belongs to a close category. The coefficient of determinants or the amount of influence of teacher performance variables on student learning outcomes in SMP Negeri Tulung Selapan is $65.1 \%$ and belongs to a fairly high influence category.

\subsection{Hypothesis Testing 3}

Hypothesis 3 testing is a hypothesis that is simultaneous or testing together.

Table 5. "F Test" Test Results

\begin{tabular}{|c|c|c|c|c|c|c|}
\hline \multicolumn{7}{|c|}{ ANOVA $^{a}$} \\
\hline & & $\begin{array}{l}\text { Sum of } \\
\text { Squares }\end{array}$ & df & Mean Square & $\mathrm{F}$ & Sig. \\
\hline \multirow[t]{3}{*}{1} & Regression & 645,827 & 2 & 322,913 & 403,652 &, $000^{6}$ \\
\hline & Residual & 178,396 & 223 &, 800 & & \\
\hline & Total & 824,222 & 225 & & & \\
\hline
\end{tabular}

Source: processed data (October 2020)

There is a significant and positive influence of teacher learning management and performance simultaneously on the learning outcomes of students at SMP Negeri Tulung Selapan Subdistrict. The amount of 
influence of both free variables on bound variables can be seen in the following table.

Table 6.Coefficient of Determinants (H3)

\begin{tabular}{|l|c|r|r|r|}
\hline \multicolumn{5}{|c|}{ Model Summary } \\
\hline Model & R & R Square & $\begin{array}{c}\text { Adjusted R } \\
\text { Square }\end{array}$ & Std. Error of the Estimate \\
\hline 1 &, $885^{2}$ &, 784 &, 782 &, 89442 \\
\hline
\end{tabular}

Source: processed data (October 2020)

The score of 0.885 which means $88.5 \%$ together with the management of learning and teacher performance with the results of student learning in SMP Negeri Tulung Selapan sub-district, thus fall into the category of close relationships. The management of learning and teacher performance together have an influence on the learning outcomes of students in SMP Negeri Tulung Selapan as much as $78.4 \%$ and fall into the category of high influence.

\subsection{The impact of learning management on student learning outcomes}

Learning management is intended as governance carried out by the school in organizing learning in the classroom. This research was conducted by testing the hypothesis through regression analysis, so that it is known that $\mathrm{t}$ calculate value of $20,103>\mathrm{t}$ table is 1,971 which means that learning management has a significant and positive influence on student learning outcomes in SMP Negeri Tulung Selapan SubDistrict.

The results achieved in this study corroborate previous research that has been conducted by Abdurohman [9], that learning management is able to realize student learning achievement optimally. Therefore, it is fitting that learning management becomes one of the aspects considered in the implementation of education in schools. A similar thing happened in the research conducted by Ratnawati [6], that learning management has an impact on teacher performance in realizing student learning achievement. So, the teacher's performance will also be affected if the learning management is done appropriately.

Another research that was also strengthened through the results obtained from this research is Rosalina's research [10], which previously stated that learning motivation can be optimal with good learning management, so are the students' learning outcomes. Similarly, Pratiwi research [11], class management as part of learning management is able to have a positive impact on students' learning outcomes.

\subsection{The effect of teacher performance on student learning outcomes}

The coefficient of determinants or the amount of influence of teacher performance variables on student learning outcomes in SMP Negeri Tulung Selapan is $65.1 \%$ and belongs to a fairly high influence category. The results of this study strengthen the research conducted previously by Abdurohman [12], that the performance of teachers contributes positively to optimizing student learning outcomes. Similarly, Diyanto stated (2016), that the teacher's performance is able to give a positive impact on the learning outcomes of students of SMK Palapa Semarang. So, the consistency of this variable has a positive influence, because other research stated that the performance of teachers plays an important role in optimizing student learning outcomes [13][14][15].

If these studies are well observed, then every teacher who has good performance is able to give a positive and significant influence on student learning achievement. Therefore, it is desirable for educators to continue optimizing their performance.

\subsection{The impact of learning management and teacher performance on student learning outcomes}

The test conducted by the researchers stated that the value of $F$ calculate is 403,652 > F Table of 3,036 which means there is a positive and significant influence of learning management and teacher performance simultaneously on the learning outcomes of students in SMP Negeri Tulung Selapan SubDistrict.

$88.5 \%$ of the teachers' learning and performance management are related to the learning outcomes of students at SMP Negeri Tulung Selapan sub-district, thus fall into the category of close relationships. Together with the management of learning and teacher performance has an influence on the learning outcomes of students in SMP Negeri Tulung Selapan district by $78.4 \%$ and falls into the category of high influence. As stated also by Najib \& Elhefni [16] that meaningful learning supported by good learning management is one of the factors that influence learning outcomes.

Based on results of partial tests conducted by researchers were able to accept alternative hypotheses compiled, as well as alternative hypotheses for simultaneous testing. Of course, this is an important concern for educational people to continue to do good management about learning and improving teacher competence so that their performance becomes better. 


\section{CONCLUSION}

Discussion of the results that have been tested in this research, increasingly complicated on important things to conclude: 1) learning management has a significant and positive influence on the learning outcomes of students in SMP Negeri Tulung Selapan; 2) The performance of teachers has a significant and positive influence on the learning outcomes of students in SMP Negeri Tulung Selapan; 3) Teacher learning and performance management have a significant and positive influence on the learning outcomes of junior high school students in Tulung Selapan district. The amount of the relationship between the three variables is $88.5 \%$ and categorized as having a very close relationship. The amount of impact of both independent variables on dependent variables is $78.4 \%$ and belongs to the category of high influence.

\section{ACKNOWLEDGMENT}

The researchers acknowledge everyone who contributed to the writing of this work, especially to the University of PGRI Palembang and the Education Office of Ogan Komering Ilir Regency.

\section{REFERENCES}

[1] Kementerian Pendidikan Nasional. (2003). Undang-undang Nomor 20 Tahun 2003 tentang Sistem Pendidikan Nasional. Jakarta: Kementerian Pendidikan Nasional.

[2] Rohman, M., \& Sofan, A. (2013). Strategi dan desain pengembangan sistem pembelajaran. Jakarta: Prestasi Pustaka.

[3] Rusyan, T. (2000). Upaya meningkatkan budaya kinerja guru. Cianjur: Dinamika Karya Cipta.

[4] Sudjana, N. (2009). Penilaian hasil proses belajar mengajar. Bandung: Remaja Rosdakarya.

[5] Dimyati, \& Mudjiono. (2013). Evaluasi pembelajaran. Jakarta: Rineka Cipta.

[6] Ratnawati. (2018). Pengaruh manajemen pembelajaran terhadpa kinerja guru dalam mewujudkan prestasi belajar siswa. Khazanah Akademia, Volume 2 No 1, 63-73.

[7] Arikunto, S. (2010). Prosedur penelitian suatu pendekatan praktik. Jakarta: Rineka Cipta.
[8] Sugiyono. (2017). Metode Penelitian Kualitatif, Kuantitatif dan $R \& D$. Bandung: Alfabeta.

[9] Abdurohman, A. (2018). Pengaruh manajemen pembelajaran terhadap kinerja guru dalam mewujudkan prestasi belajar siswa. Jurnal Pendidikan Universitas Garut, Volume 12 No 1 , $1-11$.

[10] Rosalina, T. (2012). Pengaruh manajemen pembelajaran full day school terhadap motivasi belajar. Manajemen Pendidikan, Volume 23 No 5 , 434-438.

[11] Pratiwi, Y. (2017). Pengaruh manajemen kelas terhadap hasil belajar siswa di Sekolah Menengah Pertama Negeri 1 Pedamaran, Ogan Komering Ilir. Palembang: Universiitas Islam Negeri Raden Fatah.

[12] Diyanto, E. W. (2016). Pengaruh manajemen kurikulum dan kinerja guru terhadap hasil belajar siswa SMK Palapa Semarang. Semarang: Universitas Negeri Semarang.

[13] Trianda, S. T. (2014). Pengaruh kinerja guru terhadap hasil belajar siswa kelas $\mathrm{X}$ pada mata pelajaran Ekonomi di SMA. Jurnal Pendidikan dan Pembelajaran.

[14] Rejeki, A., Triyono, \& Warsiti. (2013). Pengaruh Fasilitas Belajar dan Kinerja Guru Terhadap Hasil Belajar Matematika Kelas IV SD Se-Kecamatan Kutowinangun. Kalam Cendekia PGSD Kebumen, Volume 3 No 2.

[15] Raisyifa, D. N., \& Sutarni, N. (2016). Pengaruh kinerja mengajar guru terhadap motivasi belajar siswa. urnal Pendidikan Manajemen Perkantoran (JPManper), Volume 1 No 1, 90-98.

[16] Najib, D. A., \& Elhefni. (2016). Pengaruh Penerapan Pembelajaran Bermakna (Meaningfull Learning) Pada Pembelajaran Tematik IPS Terpadu Terhadap Hasil Belajar Siswa Kelas III di MI Ahliyah IV Palembang. Jurnal Ilmiah PGMI, Volume 2 No 1, 19-28. 